\title{
The comparison of high school students' understanding of kinematic materials: Case of question representations
}

\author{
Hellmy Nur Pratama A. Putri ${ }^{1^{*}}$, Ratih Niela $W^{2}$, Agnes Fitriana ${ }^{3}$, Sentot Kusairi ${ }^{4}$ \\ 1,2,3 Magister Program of Physics Education, Faculty of Mathematics \& Science, Universitas Negeri Malang \\ ${ }^{4}$ Department of Physics, Faculty of Mathematics \& Science, Universitas Negeri Malang
}

*Corresponding Address: hellmyputri94@gmail.com

\begin{abstract}
Article Info
Article history:

Received: March 6 ${ }^{\text {th }}, 2020$

Accepted: October $7^{\text {th }}, 2020$

Published: October $29^{\text {th }}, 2020$

\section{Keywords:}

Understanding of concept; Representation;

Public and private high school students

ABSTRACT

This present study aimed to compare kinematic concepts between public and private high school students regarding the type of questions representation. Therefore, this quantitative and descriptive study applied survey methods in conducting the research. One hundred ninety students of private high school and 199 students of public high school were involved as the research subjects. This study's primary instrument was an isomorphic multiple-choice test developed into verbal representations, pictures, and graphics. Specifically, this research instrument was adapted from the Force Motion Concept Evaluation (FMCE) and High School National Exam, validated with a reliability of 0.74 . A descriptive statistical and inferential independent t-test was used as the data analysis. Consequently, the results showed significant differences in conceptual understanding between private and public high school students. The concept of understanding in private high school was lower than in public high school, evidenced by the average scores of public high school students by 42,68 and private high school students by 22,93 . High school students can answer questions over verbal representation instead of understanding the concepts with graphical representations.
\end{abstract}

(C) 2020 Physics Education Department, UIN Raden Intan Lampung, Indonesia.

\section{INTRODUCTION}

First of all, the understanding of concepts has a vital role in the learning process. The learning process will be said as successful when students' information can lead them to master the concepts (Schunk, 2012). Besides, The concept of understanding is also one of the learning objectives (Brewe et al., 2016). The right and scientific concepts will be surely helping students to solve problems (Nieminen et al., 2010). Nevertheless, an inadequate understanding of concepts can also possibly hinder the students' capability during the learning process (Artiawati et al., 2016). The understanding concept would become maximum and efficient when students regularly practice from the basic to the main context (Docktor \& Mestre, 2014).
In this case, students need to understand well about kinematics as the basic concept. This concept is generally related to daily life. Furthermore, kinematics is a prerequisite concept to master the other next concepts (Sutrisno, 2019). Students must have a complete comprehension of position graphics, time speed, and velocity in one dimension to understand the kinematics (Zavala et al., 2017). Yeo \& Gilbert (2017) argued that perfect concepts understanding is still less enough by knowing its subconcepts. However, students can use multiple representations to solve problems.

Students' representation in the aspect of kinematics is portrayed based on the concept in each course materials. Competent students would doubtlessly express every 
representation from several tangible contexts so that they form a study mental model (Redish, 2005). Student's representation that is commonly used in this context is pictorial, textual, and graphical (Yeo \& Gilbert, 2017). Learning efforts are needed to understand the context correctly by connecting scientific experiments' findings with the scientific conceptual basis (Müller et al., 2017; Redish, 2005). Thus, it leads to the learning of multiple representations that needs more effort (Redish, 2005).

Recent studies have revealed that students' understanding of the kinematics concept is still few (Bayraktar, 2009; Hofer et al., 2017; McDermott et al., 1987). A couple of factors that cause the understanding of kinematics concepts are still low, i.e., first, students have their own conceptual, which are not following the scientific concept (Dega et al., 2013). The second is most students have naïve conceptual (Hofer et al., 2017). The third says that students have difficulties applying the symbols along with their fissions (Planinic, 2013). The fourth factor, students cannot identify the primary information of fission questions that were given (Planinic et al., 2012). Fifth, students tend to deem physics as a rote formula (Kabil, 2015). Likewise, students having difficulties interpreting the graphics into the physics concepts (McDermott et al., 1987). The last factor is that wrong conceptual also happens to teacher candidates or teachers, so that it influences students' understanding of the concepts (Suprapto et al., 2018).

There are lots of studies that have discussed students' understanding of the kinematics concept in Indonesia. One example is (Rohmah \& Handhika, 2018) had researched kinematics misconception. Students of Grade X in Islamic High School still had several $27 \%$ misconceptions and did not understand the concepts by $55 \%$. Artiawati et al., (2016) researched the misconception of Regular Straight Motion materials at SMA Negeri Kota Singkawang. It turned out that there were still high misconceptions about the concept of speed and velocity.

Moreover, the study of students' kinematics concept understanding was also done by (Sutrisno, 2019) on students at private High Schools in Bandung. However, there has not been a discussion that deconstructs to compare the understanding of kinematics and its representation between private and public schools. Therefore, this present study aims to compare students' understanding of the concepts in question representation.

\section{METHODS}

This present study applied a quantitativedescriptive approach as the research method. Henceforth, the design was a type of nonexperimental, so that the research steps were illustrated in the following Figure 1,

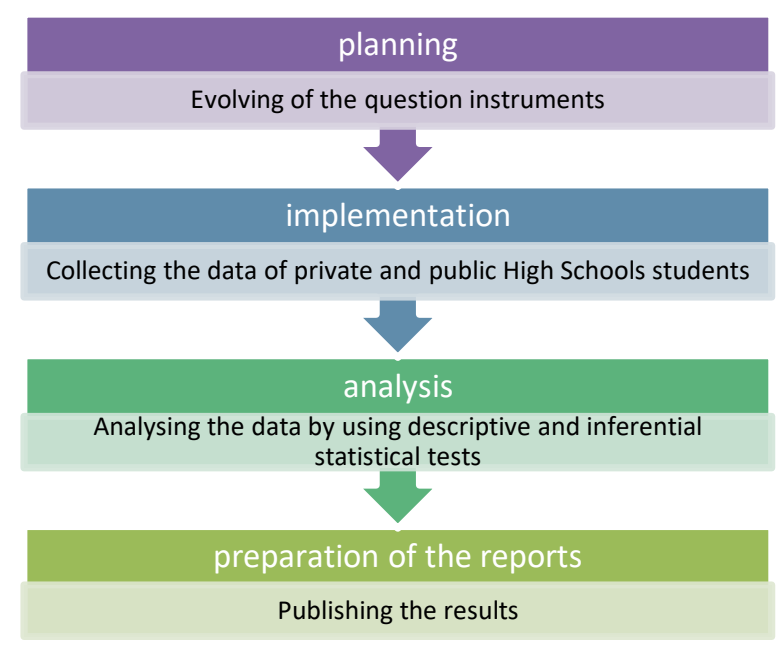

Figure 1. Research schemes

The first step or planning included selecting the right time and choosing the right technique to collect the data. The next step was continued by collecting the corresponding data. The data collection technique used was a test. The questions consisted of multiple representations, i.e., verbal, pictorial, and graphics. The number of items is nine questions. Seven multiplechoice questions were adapted from national exam questions and the other two questions about Force Motion Concept Evaluation (FMCE) on the straight motion, validated and 
reliable (Hestenes et al., 1992). Each context had three items of the question, which was isomorphic with different questions representation. These isomorphic questions had the excellence of detecting an understanding of concepts quickly and accurately (Kusairi et al., 2017). Table 1 is the distribution of concept comprehensive questions and the evaluation test.

The implementation step, likewise, called data collection, was done by applying the instruments adapted to the public and private high schools. There were 190 students at private High School and 199 students of public High School involving as the research subject. Both school institutions had been being accredited $\mathrm{A}$. students had studied the materials of Regular Straight Motion, and they did not participate in any tutoring out of school hours.

The step of analyzing was beginning by calculating students' scores. The scoring technique used a binary system, i.e., the number score of 1 for correct answers and 0 for the wrong ones. Henceforth, the obtained scores were grouped based on their context and representation. The final score of each indicator was analyzed by using the following calculations.

Table 1. Conversion of scores on isomorphic tests

\begin{tabular}{cc}
\hline Scores of each context & Values \\
\hline 0 & 0 \\
1 & 0 \\
2 & 1 \\
3 & 2 \\
\hline
\end{tabular}

$$
\text { score }=\frac{\text { total score }}{3} \times 100
$$

(Dou \& Zwolak, 2019)

The next step was calculating reliability, discriminating index, level of difficulty, and biserial point. The results were shown in Table 2.

Table 2. Internal consistency of the instrument

\begin{tabular}{|c|c|c|c|c|c|}
\hline $\begin{array}{l}\text { Descriptions of } \\
\text { Indicator }\end{array}$ & $\begin{array}{c}\text { Representatio } \\
\text { ns }\end{array}$ & $\begin{array}{l}\text { Discrimina } \\
\text { ting Index }\end{array}$ & $\begin{array}{l}\text { Levels of } \\
\text { Difficulty }\end{array}$ & $\begin{array}{l}\text { Biserial } \\
\text { Point }\end{array}$ & Reliability \\
\hline \multirow{3}{*}{$\begin{array}{l}\text { Applying the concept } \\
\text { of displacement by } \\
\text { using pictorial or } \\
\text { verbal representations }\end{array}$} & Pictorial & 0,01 & 0,59 & 0,23 & \multirow[t]{9}{*}{0,74} \\
\hline & Pictorial & 0,52 & 0,44 & 0,27 & \\
\hline & Pictorial & 0,33 & 0,76 & 0,31 & \\
\hline \multirow{3}{*}{$\begin{array}{l}\text { Applying the concept } \\
\text { of speed by using } \\
\text { verbal, graphic, or } \\
\text { pictorial } \\
\text { representations }\end{array}$} & Verbal & 0,81 & 0,59 & 0,39 & \\
\hline & Graphic & 0,85 & 0,46 & 0,22 & \\
\hline & Pictorial & 0,11 & 0,17 & 0,19 & \\
\hline \multirow{3}{*}{$\begin{array}{l}\text { Analyzing the concept } \\
\text { of velocity in graphics }\end{array}$} & Graphic & 0,04 & 0,76 & 0,45 & \\
\hline & Graphic & 0,29 & 0,15 & 0,48 & \\
\hline & Graphic & 0,59 & 0,41 & 0,28 & \\
\hline
\end{tabular}

The data analysis was performed into descriptive and inferential of independent $t$ test equal value not assumed. It occurred mainly since the data was usually distributed, but it refused the homogeneity to determine the conceptual understanding between public and private students.

\section{RESULTS AND DISCUSSION}

The results of the descriptive statistical test of students' conceptual comprehension are performed in Table 3. 
Table 3. Descriptive and inferential statistics

\begin{tabular}{lllll}
\hline $\begin{array}{l}\text { descriptive } \\
\text { Analysis }\end{array}$ & $\begin{array}{l}\text { Private } \\
\text { High } \\
\text { School }\end{array}$ & $\begin{array}{l}\text { Public } \\
\text { High } \\
\text { School }\end{array}$ & $\begin{array}{l}\text { Inferent } \\
\text { ial } \\
\text { Analysi } \\
\text { s }\end{array}$ & $\begin{array}{l}\text { Re } \\
\text { sul } \\
\text { ts }\end{array}$ \\
\hline $\begin{array}{l}\text { Average } \\
\text { value }\end{array}$ & 42,68 & 61,83 & $\begin{array}{l}\text { Indepen } \\
\text { dent t- }\end{array}$ & 7,8 \\
$\begin{array}{l}\text { Deviation } \\
\text { standard }\end{array}$ & 22,93 & 27,94 & test & \\
Median & 44 & 67 & Signific & 0,0 \\
Max. score & 100 & 100 & ance & 01 \\
Min. score & 0 & 44 & df & 2 \\
\hline
\end{tabular}

The descriptive tabulation above shows that students' understanding of the kinematics concept at public High School tends to be higher than at private High School. Meanwhile, private High schools tend to have an extensive range in understanding the concept. It is also indicated by the results of inferential statistics using an independent t-test. The obtained significance level is 0.0001 , which means that there are significant differences between the two samples. It shows differences in understanding the concept of kinematics between public and private high schools and students.

This research found that public-school students' understanding of the kinematics concept was higher than private school students. The result was the same as a research by (Afriana, 2016) which conveyed that understanding the kinetics gas theory concept in public school was higher than in private school. This was due to internal and external factors. The social situation could be categorized as an external factor, such as the teachers' factor from both schools. In several cases, it influenced the learning atmosphere during classroom activities (Senler, 2016). (Senler, 2016) said that teacher's selfefficacy commonly influenced the learning atmosphere.

Meanwhile, the internal factor was the effect of the external factor. Self-adjustment from the external factor might affect academic achievement in mindset, learning achievement, and learning independence, which could also be different in each institution (Arifin et al., 2016).
Overall, there are $52 \%$ of correct answers. It indicates that students' ability to understand the concept has not achieved the minimum criteria yet. Meanwhile, the standard of minimum criteria in Indonesia is $70 \%$. Hence, students have not understood well the context of displacement, speed, and velocity. This result is immensely dissimilar compared to the Singapore student's understanding of the concept, which stands on the number of $85 \%$ of the minimum criteria of $80 \%$ (Yeo \& Gilbert, 2017). Concept understanding based on subconcepts can be tabulated in Table 4 .

Table 4. Understanding viewed from the context

\begin{tabular}{lllll}
\hline Context & $\begin{array}{l}\text { Private } \\
\text { High } \\
\text { School }\end{array}$ & $\begin{array}{l}\text { Interp } \\
\text { retatio } \\
\text { n }\end{array}$ & $\begin{array}{l}\text { Public } \\
\text { High } \\
\text { School }\end{array}$ & $\begin{array}{l}\text { Interp } \\
\text { retati } \\
\text { on }\end{array}$ \\
\hline $\begin{array}{l}\text { Displace } \\
\text { ment }\end{array}$ & $22 \%$ & TL & $38 \%$ & TL \\
$\begin{array}{l}\text { Speed } \\
\text { Velocity }\end{array}$ & $12 \%$ & TL & $28 \%$ & TL \\
\hline
\end{tabular}

The context that is successfully understood by students from the two schools in the displacement. In other words, students have already understood the necessary context of kinematics. Conversely, students find it hard to understand the speed. Those results, however, are not compatible with the framework of thinking. Supposedly, if students understand the context of speed, they should have understood the context of velocity formerly. This case indicates that students tend to understand each context separately, and there is no relatedness between one context and another. Besides, students deem that speed is a scalar quantity and does not depend on its direction (Docktor \& Mestre, 2014)

The following graph illustrates the representation score of each school show in Figure 2, 


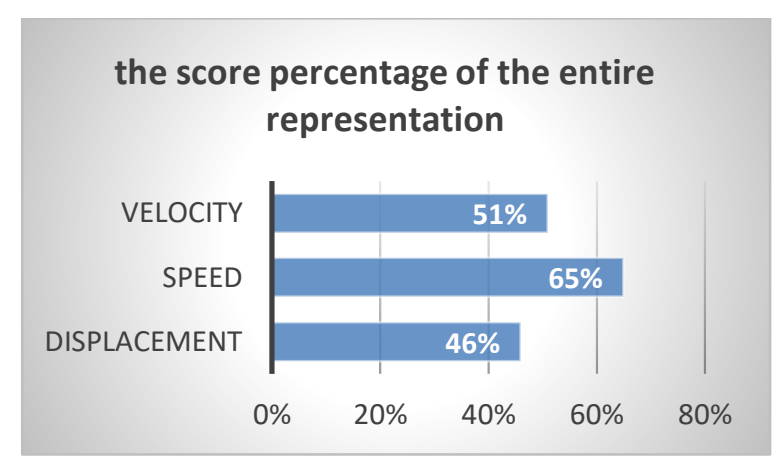

Figure 2. Score percentage of the entire representations

Figure 2 explains that verbal is a representation that is considered accessible and successfully understood by students. Students have been able to identify the information and to associate symbols into the context of physics. The scoring percentage of students' representation is depicted according to its institution show in Figure 3,

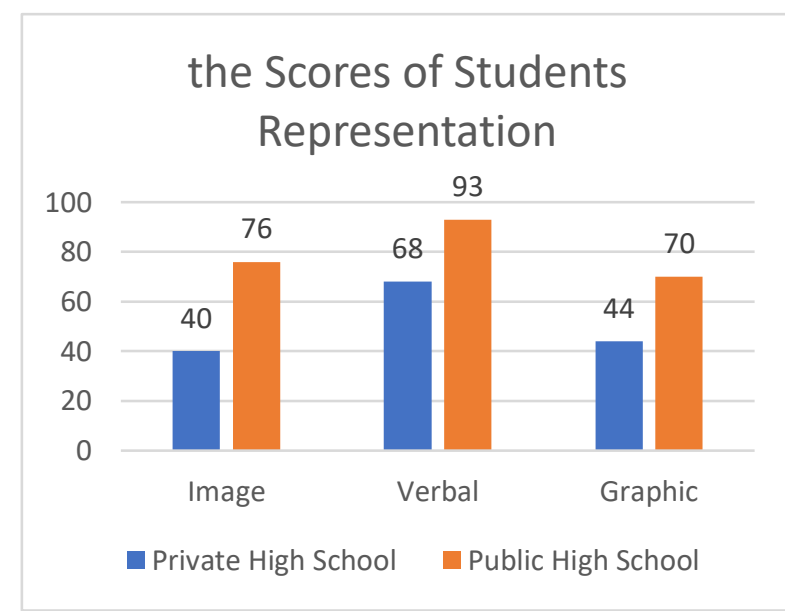

Figure 3. Score of students' representations

Figure 3 shows that students tend to understand the concept by using verbal representation quickly. Private High School students find it hard to understand the concept using pictorial representation, whereas Public High School students find it hard to represent the graphic.

The graphic was one of the representations that students at the public high school deemed challenging to understand. It happens because students were less able to associate physics concepts with the graphic forms. In the same token, this finding was supported by the recent studies of (McDermott et al., 1987) and (Beichner, 1996) which revealed that students could not interpret the graph into the physics context. Despite this problem, however, the graphical representation could still be improved by illustrating the phenomenon analyzed using a computer. The other alternative was the research of (Zavala et al., 2017) that suggested the teachers should get used to using isomorphic tests. According to neuroscience theory, the isomorphic test enabled to increase synapses and strengthen memory performance (Schunk, 2012). Besides, private high school students deemed pictorial as the difficult one because they could not construe the pictorial into the physics context. Also, students found it challenging to process the given information either cognitively or metacognitively. They were less able to generalize the pictorial into its context (Opfermann et al., 2017). Those findings correspond to the same with research by (Ainsworth et al., 2016), which claimed that a pictorial representation needed deep reasoning.

In indicator 2, with a difficulty level of $0.17,29 \%$ of 389 respondents answered questions correctly. The question items are written show in Figure 4,

A car is moving with a speed $v$ and a velocity $a$, the direction of its tire movement as shown in that Figure. There is no slip on the car tires. Which one is the direction of speed at point A on the tire?
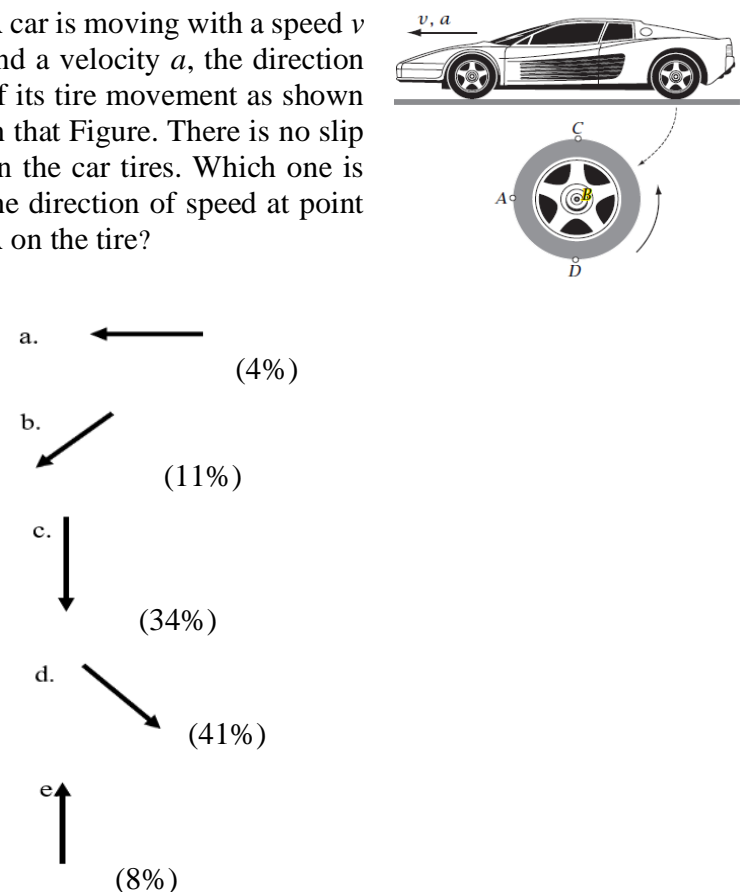

Figure 4. The Hardest to Answer Question 
This case indicates that most students have difficulties within the aspect of pictorial representation. The context of the number 8 question is to decide the speed direction. Students mostly chose option D. Based on the option they mostly choose; it implicitly tells that the direction of tire speed is considered the same with its tire shape. Question of number 8 (the aspect of pictorial representation) was improved by using learning that can lead students to deputize a claim, giving the elucidation over the question and answer, and giving further manipulation of the representation, refinement, discussion, and critical thinking to reflect, confirm, or modify phenomena (Sutopo \& Waldrip, 2014).

Despite former elaborations, those studies above are researched (Saputra et al., 2019; Sutopo et al., 2020). Students still have difficulties studying multiple representations (especially graphic representation), and their understanding of the concept is still intermittent or knowledge in pieces. However, this present study differs this research from (Sutopo et al., 2020) in question instruments and the number of respondents. This present study takes an isomorphic test while (Sutopo et al., 2020) use 20 items of multiple-choice questions. Additionally, this present study has similarities with (Saputra et al., 2019), which is students cannot solve the physics question in any representation. This present study can be generalized as; there are fewer errors results in measurements, and these results can be utilized as teachers' reference at public and private schools; hence, the resulting survey from both schools is different.

It is recommended for the teachers and the learning instructors to improve students' understanding of the concept by doing; first, design the context according to the schemes that students have so that their learning process becomes meaningful. Second, the teacher should give more elaborations that each context must be related to each other so that students can understand the context entirely. Third, the teacher needs to know students' laxities to guide them to become better in solving each level of the difficulty by using better media to stimulate them to understand the new representation easily.

Also, this present study's weakness is that the multiple-choice instrument can guess the right answer. The second is the possibility of cheating. The third one is that the representation of each indicator does not have the same quality. However, the next study is also recommended to develop a better instrument by giving three representations of each indicator.

\section{CONCLUSION AND SUGGESTION}

As has been noted, public High School students' understanding of kinematics concepts was higher than private High School students. The successfully understood context by students of the two schools was the context of displacement. Overall, students tended to consider verbal representation as to the easiest one. Public High School students deemed graphic representation as to the hardest while private High School students deemed pictorial representation as to the hardest one.

\section{AUTHOR CONTRIBUTIONS}

$\mathrm{HN}$ and AF developing question instrument. SK and RN collected, analyzed and display data. $\mathrm{HN}$ reviewing the literature that is in accordance with this research. All authors wrote the manuscript.

\section{REFERENCES}

Afriana, J. (2016). Penggunaan multimedia dalam pembelajaran teori kinetik gas di SMA/MA negeri dan swasta kecamatan Sambas. Jurnal Pendidikan Matematika dan IPA, 4(2). https://doi.org/10.26418/jpmipa.v4i2.1 7590

Ainsworth, S., Stieff, M., DeSutter, D., Tytler, R., Prain, V., Panagiotopoulos, D., Wigmore, P., van Joolingen, W., Heijnes, D., Leenaars, F., \& Puntambekar, S. (2016). Exploring the 
value of drawing in learning and assessment. Semantic Scholar 8.

Arifin, M., Dardiri, A., \& Handayani, A. N. (2016). Hubungan kemampuan penyesuaian diri dan pola berpikir dengan kemandirian belajar serta dampaknya pada prestasi akademik mahasiswa. Jurnal Pendidikan: Teori, Penelitian, dan Pengembangan. 1(10), 943-1951.

Artiawati, P. R., Mulyani, R., \& Kurniawan, Y. (2016). Identifikasi kuantitas siswa yang miskonsepsi menggunakan three tier-test pada materi gerak lurus beraturan (HLB). JIPF (Jurnal Ilmu Pendidikan Fisika), 1(1), 13-15. https://doi.org/10.26737/jipf.v1i1.54

Bayraktar, S. (2009). Misconceptions of Turkish Pre-Service Teachers about Force and Motion. International Journal of Science and Mathematics Education, 7(2), 273-291. https://doi.org/10.1007/s10763-0079120-9

Beichner, R. J. (1996). The impact of video motion analysis on kinematics graph interpretation skills. American Journal of Physics, 64(10), 1272-1277. https://doi.org/10.1119/1.18390

Brewe, E., Bruun, J., \& Bearden, I. G. (2016). Using module analysis for multiple choice responses: A new method applied to force concept inventory data. Physical Review Physics Education Research, 12(2). https://doi.org/10.1103/PhysRevPhysE ducRes.12.020131

Dega, B. G., Kriek, J., \& Mogese, T. F. (2013). Students' conceptual change in electricity and magnetism using simulations: A comparison of cognitive perturbation and cognitive conflict. Journal of Research in Science Teaching, 50(6), 677-698. https://doi.org/10.1002/tea.21096

Docktor, J. L., \& Mestre, J. P. (2014). Synthesis of discipline-based education research in physics. Physical Review Special Topics - Physics
Education Research, 10(2), 020119. https://doi.org/10.1103/PhysRevSTPE R.10.020119

Dou, R., \& Zwolak, J. P. (2019). Practitioner's guide to social network analysis: Examining physics anxiety in an active-learning setting. Physical Review Physics Education Research, 15(2), 020105. https://doi.org/10.1103/PhysRevPhysE ducRes.15.020105

Hestenes, D., Wells, M., \& Swackhamer, G. (1992). Force concept inventory. The Physics Teacher, 30(3), 141-158. https://doi.org/10.1119/1.2343497

Hofer, S. I., Schumacher, R., \& Rubin, H. (2017). The test of basic Mechanics Conceptual Understanding (bMCU): Using Rasch analysis to develop and evaluate an efficient multiple-choice test on Newton's mechanics. International Journal of STEM Education, $\quad 4(1), \quad 18$. https://doi.org/10.1186/s40594-0170080-5

Kabil, O. (2015). Philosophy in physics education. Procedia - Social and Behavioral Sciences, 197, 675-679. https://doi.org/10.1016/j.sbspro.2015. 07.057

Kusairi, S., Hidayat, A., \& Hidayat, N. (2017). Web-based diagnostic test: introducing isomorphic items to assess students' misconceptions and error patterns. Chemistry Bulgarian Journal of Science Education. (4) 15.

McDermott, L. C., Rosenquist, M. L., \& van Zee, E. H. (1987). Student difficulties in connecting graphs and physics: Examples from kinematics. American Journal of Physics, 55(6), 503-513. https://doi.org/10.1119/1.15104

Müller, A., Hettmannsperger, R., Scheid, J., Scheid, \& Schnotz, W. (2017). Representational competence, understanding of experiments, phenomena and basic concepts in geometrical optics: A representational approach. Springer International 
Publishing AG 2017, Models and Modeling in Science Education 10. https://doi.org/10.1007/978-3-31958914-5_10

Nieminen, P., Savinainen, A., \& Viiri, J. (2010). Force concept inventory-based multiple-choice test for investigating students' representational consistency. Physical Review Special Topics Physics Education Research, 6(2). https://doi.org/10.1103/PhysRevSTPE R.6.020109

Opfermann, M., Schmeck, A., \& Fischer, H. E. (2017). Multiple Representations in Physics and Science Education - Why Should We Use Them? In D. F. Treagust, R. Duit, \& H. E. Fischer (Eds.), Multiple Representations in Physics Education (Vol. 10, pp. 1-22). Springer International Publishing. https://doi.org/10.1007/978-3-31958914-5_1

Planinic, M. (2013). Comparison of university students' understanding of graphs in different contexts. Physical Review Special Topics - Physics Education Research, 9(2). https://doi.org/10.1103/PhysRevSTPE R.9.020103

Planinic, M., Milin-Sipus, Z., Katic, H., Susac, A., \& Ivanjek, L. (2012). Comparison of student understanding of line graph slope in physics and mathematics. International Journal of Science and Mathematics Education, 10(6), 1393-1414. https://doi.org/10.1007/s10763-0129344-1

Redish, E. F. (2005). Problem Solving and The Use of Math In Physics Courses. World View on Physics Education in 2005, 10.

Rohmah, Z., \& Handhika, J. (2018). TwoTier Test Diagnostik sebagai identifikasi miskonsepsi tahap awal materi kinematika gerak lurus siswa kelas X MIA MAN 1 Kota Madiun. Quantum: Seminar Nasional Fisika, Dan Pendidikan Fisika, O(0), 552-556.
Saputra, A. T., Jumadi, J., Paramitha, D. W., \& Sarah, S. (2019). Problem-Solving approach in multiple representations of qualitative and quantitative problems in kinematics motion. Jurnal Ilmiah Pendidikan Fisika Al-Biruni, 8(1), 8998.

https://doi.org/10.24042/jipfalbiruni.v $8 \mathrm{i} 1.3801$

Schunk, D. H. (2012). Learning theories: An educational perspective (6th ed). Pearson.

Senler, B. (2016). Pre-service science teachers' self-efficacy: The role of attitude, anxiety and locus of control. Australian Journal of Education, 60(1), 26-41. https://doi.org/10.1177/000494411662 9807

Suprapto, N., Suliyanah, Prahani, B. K., Jauhariyah, M. N. R., \& Admoko, S. (2018). Exploring physics concepts among novice teachers through CMAP tools. Journal of Physics: Conference Series, $\quad 997, \quad 012011$. https://doi.org/10.1088/17426596/997/1/012011

Sutopo, Hidayah, N., Wisodo, H., \& Haryoto, D. (2020). Improving students' understanding of kinematics concepts through multirepresentational learning. AIP Conference Proceeding. 2215. 030026.

https://doi.org/10.1063/5.0004063

Sutopo, \& Waldrip, B. (2014). Impact of a representational approach on students' reasoning and conceptual understanding in learning mechanics. International Journal of Science and Mathematics Education, 12(4), 741765. https://doi.org/10.1007/s10763013-9431-y

Sutrisno, A. D. (2019a). Survey pemahaman konsep dan identifikasi miskonsepsi siswa SMA pada materi kinematika gerak. WaPFi (Wahana Pendidikan Fisika), 4(1), 106-112. 
Yeo, J., \& Gilbert, J. K. (2017). The role of representations in students' explanations of four phenomena in physics: dynamics, thermal physics, electromagnetic induction and superposition. In D. F. Treagust, R. Duit, \& H. E. Fischer (Eds.), Multiple Representations in Physics Education (Vol. 10, pp. 255-287). Springer International Publishing. https://doi.org/10.1007/978-3-31958914-5_12

Zavala, G., Tejeda, S., Barniol, P., \& Beichner, R. J. (2017). Modifying the test of understanding graphs in kinematics. Physical Review Physics Education Research, 13(2). https://doi.org/10.1103/PhysRevPhysE ducRes.13.020111 